\title{
THE CORRELATION BETWEEN STUDENTS' SIMPLE PAST TENSE MASTERY AND THEIR ABILITY IN TRANSLATING NARRATIVE TEXT AT THE FIRST YEAR OF SMA NEGERI 5 PAREPARE
}

\author{
Masriani $^{1}$, Amzah Selle ${ }^{2}$ \\ Institut Agama Islam Negeri (IAIN) Parepare ${ }^{12}$ \\ masrianiarsyad3@gmail.com ${ }^{1}$
}

\begin{abstract}
This research aims atto see the correlation between students' simple past tense mastery and their ability in translatingnarrative text in the first year of SMA Negeri 5 Parepare. The results of the research are useful for the teacher and students. The teacher will aware that it is important to teach simple past tense to the students before asking to translate the narrative text and the students also can be easier translate the narrative text when they master in the simple past tense. The subject of this research is X Mia 4 class which is consisted of 22 students. The sample was taken by using purposive sampling. The design in this research was descriptive quantitative by giving a grammar test and translation test. Grammar test consists of 15 numbers multiple choices about simple past tense and students were given a narrative text to translate. The result of the tests showed that there is a correlation between students' simple past tense mastery and their ability in translatingnarrative text. Students who had a high score in simple past also had a high score in translating narrative text but students who had a low score in simple past tense also had a low score in translating narrative text.
\end{abstract}

Keywords: Simple Past Tense, Translating, Narrative Text.

\section{Introduction}

English is a foreign language must be known by all of the people in Indonesia specially for the young generation because they can get many bits of knowledge and information from the other countries by listening or reading English text. As people learn English, they involved in the process of learning four skills namely speaking, writing, reading and listening (A.Kaharuddin Bahar, 2014). The four skills are learned start from elementary school, junior high school, senior high school to University. To be a master of them, it is not enough only to learn from school but also we should learn in course. Besides the four skills of language, there are some elements also in the language that the learners should know such as grammar.The Oxford Learner Pocket Dictionary, Grammar rules for 
forming words and making sentences. It is important to be taught to the students because it will make them easier to use and understand the language correctly and effectively.

Most of the students translate the text word by word so they cannot reach the contextual meaning of the text. It happens because they don't understand the verb form used of the text. The simple past tense indicates that an activity or situation began and ended at a particular time in the past (Betty Schrampfer Azar, 1989). The narrative text is a kind of text which the contents tell a fictive story happened in the past time. It means that verb form used in the narrative text is past tense.

Sometimes the students were given the task to translate narrative text but the teachers do not explain simple past tense. It makes the students' difficult to do that task so it includes teacher's deviation in teaching English.

From the explanation above, the researcher was interested to do her research in SMAN 5 Parepare because the researcher has known the simple past tense mastery of the students in that school. Several students have been master in the simple past tense, they know the pattern of simple past tense and make the simple past sentence but many students still don't know the use of simple past tense.

The students who are master and had a high score in the simple past tense task will have a good ability in translating narrative text. To know the fact, the researcher decided to determine the title of her research "The Correlation Between Students' Past Tense Mastery and Their Ability in Translating Narrative Text".

In relation with the background above, the problem statement of the research can be stated as follow: "Is there any correlation between students' simple past tense mastery and their ability in translating the narrative text?" The objective of the research: To know the correlation between students' simple past tense mastery and their ability in translating narrative text.

Based on the problem statement above, the researcher forward hypothesis as follows: Alternative Hypothesis (Ha): there is a correlation between simple past tense mastery and the ability in translating a narrative text of the first-year students at SMA Negeri 5 Parepare. 
There are some significances of the research, as follows: For the English teachers and researchers, this research is expected can change the mind-set of the teachers to be a professional in teaching English to make the students' understand well about the material before giving the task. For the students, this research can be motivated the students to learn grammar seriously to understand the English text. For the readers, it can enlarge the knowledge of the reader about the grammar especially simple past tense and translation then inform them about the correlation between the students' past tense mastery and their ability in translating in narrative text.

\section{Method}

The research design of this research was descriptive quantitative. It aims to describe the correlation between past tense mastery and the ability in translating narrative text at the first year students of SMAN 5 Parepare.

In this research, the researcher used person product moment with casual correlation. The location of the research took a place at SMAN 5 Parepare. The researcher did the research more than one month for collecting data.

The population of the research was the first year students of SMAN 5 Parepare academic year 2017/2018. There are 4 classes in that school which are X.Mia $1=24$, X.Mia $2=26$, X.Mia $3=26$, and X.Mia $4=22$. The total of population were98 students.

The sample took by using purposive sampling. The researcher took the class XI. Mia 4 which is consists of 22 students as the sample in this research because this class is more active than other classes.

In collecting data, the researcher gave two kinds of tests on Friday, March 30th, 2018 which are grammar test and translation test. Both of the tests were in written form.

In a grammar test, the researcher gave the multiple-choice test because the technique of scoring was easy and practical. In multiple choices, items consist of a premise and several alternative answers. The students chose one of the alternative answers which are the correct answers. The researcher gave fifteen items and thirty minutes for students to do the test. In the translation test, the students were given the narrative text and asked to translate the narrative. They were given sixty minutes to do the test. Each student got one text to translate and they had to do by themselves without cheating one another. 
The procedures of collecting data in this research, as follows: The researcher introduced herself to the students, the researcher gave appreciation to the students before giving the tests and explained the purpose of doing the tests. the researcher informed the students that the grammar test was about past tense which is consists of fifteen items and gave them thirty minutes to do. After that, they were given the narrative text to be

\begin{tabular}{cccccc}
\hline $\mathrm{N}$ & $\mathrm{X}$ & $\mathrm{Y}$ & $\mathrm{XY}$ & $\mathrm{X}^{2}$ & $\mathrm{Y}^{2}$ \\
\hline 22 & $\sum \mathrm{X}=1733$ & $\sum \mathrm{Y}=1520$ & $\sum \mathrm{XY}=131355$ & $\sum \mathrm{X}^{2}=149477$ & $\sum \mathrm{Y}^{2}=117200$
\end{tabular}

translated and had sixty minutes to do, the researcher collected the students work.

The data were collected through the past tense and translation test. The research analyzed by using quantitative statistic. The pattern used in this research was person product moment (Sugiyono, 2013). Quality of correlation based on the value of $\mathrm{r}$ product moment.:

\begin{tabular}{cc}
\hline The value of r product moment & Intrepretation on collection quality \\
$0.00-0.199$ & Very week correlation \\
$0.20-0.399$ & Weak ccorrelation \\
$0.40-0.599$ & Middle correlation \\
$0.60-0.799$ & Strong correlation \\
$0.80-1.000$ & Very strong correlation \\
\hline
\end{tabular}

\section{Result}

This chapter contained finding and its discussion. The finding of the research coversthe result of data collected and analyzed through simple past tense test and translating narrative text test. The data will be discussed in this section below.

Where:

$$
\begin{aligned}
& r=\frac{N \sum x y-\sum x \cdot \sum y}{\sqrt{\left(N \sum x^{2}-\sum x^{2}\right)^{2}\left(N \sum y^{2}-\sum y^{2}\right)^{2}}} \\
& r=\frac{(22)(131355)-(1733)(1520)}{\sqrt{(22)(149477)-(1733)^{2}} \cdot(22)(117200)-(1520)^{2}} \\
& r=\frac{255650}{\sqrt{285205 . \sqrt{268000}}}=\frac{255650}{(534.04)(517.68)}=\frac{255650}{276461.8272}=0.924
\end{aligned}
$$


Inspiring: English Education Journal

Volume I No 2 September20I8

\begin{tabular}{cc}
\hline $\mathrm{r}=$ value & $\mathrm{r}=$ table \\
\cline { 2 - 2 } & $5 \%$ \\
\hline 0.924 & 0.423 \\
\hline
\end{tabular}

It can be concluded that $r$-value is greater than $r$-table, it means that alternative hypothesis is accepted so there is correlation between students' simple past tense mastery and their ability in translating narrative text. The students' who got high scores in past tense means they could translate the narrative text well and the students who got low scores in past tense means they were difficult to translate the narrative text.

\section{Discussion}

Table1. Classification Data

\begin{tabular}{cccccc}
\hline No & Students & Simple Past Tense & Classification & $\begin{array}{c}\text { Translating } \\
\text { Narrative Text }\end{array}$ & Classification \\
\hline 1 & S1 & 80 & Good & 65 & Good \\
2 & S2 & 87 & Good & 80 & Good \\
3 & S3 & 93 & Excellent & 85 & Good \\
4 & S4 & 80 & Good & 85 & Good \\
5 & S5 & 93 & Excellent & 70 & Good \\
6 & S6 & 100 & Excellent & 85 & Good \\
7 & S7 & 27 & Poor & 35 & Poor \\
8 & S8 & 100 & Excellent & 90 & Excellent \\
9 & S9 & 87 & Good & 85 & Good \\
10 & S10 & 67 & Good & 40 & Enough \\
11 & S11 & 87 & Good & 80 & Good \\
12 & S12 & 100 & Excellent & 90 & Excellent \\
13 & S13 & 93 & Excellent & 85 & Good \\
14 & S14 & 87 & Good & 60 & Enough \\
15 & S15 & 40 & Enough & 40 & Enough \\
16 & S16 & 100 & Excellent & 90 & Excellent \\
17 & S17 & 100 & Excellent & 90 & Excellent \\
18 & S18 & 33 & Poor & 30 & Poor \\
19 & S19 & 53 & Enough & 30 & Poor \\
20 & S20 & 33 & Poor & 35 & Excellent \\
21 & S21 & 93 & Excellent & 90 & Excellent \\
22 & S22 & 100 & Excellent & 90 & \\
\hline
\end{tabular}


From the table above, the researcher found the result of classifying students' simple past tense and translating narrative text. It showed that there were 15 students from 22 students that have the same classification between their simple past tense and their translating narrative text. There were 6 students got excellent classification in their simple past tense and translating narrative text, 5 students got good classification in their simple past tense and translating narrative text, 1 student got enough classification in their simple past tense and translating narrative text, and 3 students got poor classification in their simple past tense and translating narrative text. So, 7 students had not the same classification between their simple past tense and their translating narrative text.

It was found that the students who got higher scores in the simple past tense, they also got a high score in translating. In contrast, the students who got a low score in the simple past tense, they also got low scores in the translation test. It has happened because the students who did not understand the verb form of the past tense was difficult to translate the text that used past tense. To know well about past tense form, the students have to master regular and irregular verb.

\section{Conclusion}

The researcher concluded that there is a correlation between students' past tense mastery and the ability in translating narrative text. There is a significant correlation both of them by seeing the result of the calculating scores 0.924 . The critical value of the person $r$ with 5\% got the significance 0.423 . It means that the result of the computation is greater than the critical value. So, the researcher concluded that the correlation between past tense and translating a narrative text is highly significant. The students who master in the past tense can translate the narrative text well but the other hand, the students who are low in past tense will difficult to translate the narrative text. It was very clear from the result of students' past tense scores and their scores in translating narrative text at SMAN 5 Parepare. The hypothesis of the research was accepted.

In teaching English, the teachers should master the skills and components of language and know the ability of their students. The teacher should give the material of simple past tense to the students before asking to translate the narrative text because past 
tense is the language used in the narrative text so, if the students master the simple past tense, they will easier to translate the narrative text.

\section{References}

Arikunto, Suharsimi. 2002. Prosedur Penelitian. Jakarta: RinekaCipta.

Bahar, A. Kaharuddin.2014. Transactional Speaking. Samata Gowa: Guna Darma Ilmu.

Catford, J.C. 1965. A Linguistic Theory of Translation. Great Britain: Hazell Watson and Viney LTD Aylesbury.

Downing, Angela and Philip Locke. 2006. English Grammar A University Course: Second Edition. Taylor \& Francis: Routledge.

Elfahma, Danisa Faliha. 2015. Planet English Grammar. Jawa Timur: Ponpes Darul Ulum.

Fadly, Achmad 2013. “ The Analysis of Translation Procedures in Subtitle Hachiko Movie” Published Thesis of English Letters Department Jakarta.

Fahrurrozi, Drs. 2003. Teknik Praktis Terjemah. Yogyakarta: Teknomedia Yogyakarta.

Frank, Marcella. 1972 Modern English; A Practical Reference Guide. New Jersey: Prentice-Hall, Inc.

Hidayah, Tias Evi. 2007. “A Correlation Between Students' Mastery Of Past Tense And Their Achievement In Writing Recount.'Published Thesis of English Department Semarang.

Learningself, "Kind of Narrative," Situs Resmi FreeEnglisCourse.inf.

http://freeenglishcourse.info/kinds-of-narrative-jenismacam-narrative-text/. (2016).

Munand, Aris “ Narrative text: Definition, Purposes, Generic Structures and The Example of Narrative Text," DUOULALA.blogspot.com.

http://duoulala.blogspot.co.id/2013/07/narrative-text-definition-purposes.html January 2017).

Murphy, Raymond. 1994. English Grammar in Use: Second Edition United Kingdom: Scotprint Ltd, Musselburgh, Scotland.

Newmark, Peter 1988 A Textbook of Translation. New York: Prentice Hall.

Peat, Jennifer. 2002. Scientific Writing:Easy When You Know How London: BMJ Books. 
Safitri, Marita. 2014. "The Correlation Between The Students' Past Tense Mastery And Their Ability in Translating Narrative Texts," TheSecondInternational Conference on Education and Language 2nd ICE.

Schrampfer Betty, Azar. 1989. Understanding and Using English Grammar: Second Edition. United States of America: Prentice Hall Regents.

Septiani, Reni. 2014. "The Correlation Between Grammar Mastery and Writing Ability" Published Scrips of English Education Department Jakarta

Simajuntak, Herpinus. 2012. Bahasa Inggris Sistem 52M Jakarta: Kesaint Blanc.

Sugiyono.MetodePenelitianPendidikan, (pendekatankuantitatif, kualitatif, dan R\&D). Bandung: Alfabeta.

Thomson A.J and A.V Martinet. 1986. A Practical English Grammar: Fourth Edition. Hong Kong: Oxford University Press.

Ur, Penny. 1991. A Course in Language Teaching: Practice and Theory. Cambridge: Cambridge University Press.

Urdan, Statistic in Plan English (Second edition).

W. Brislin, Richard. 1976. Translation: Applications and Research. New York: Gardner Press,inc. 